\title{
Sperm maturation, fluid transport, and secretion and absorption of protein in the epididymis of the echidna, Tachyglossus aculeatus
}

\author{
D. Djakiew and R. C. Jones
}

Department of Biological Sciences, University of Newcastle, New South Wales 2308, Australia

\begin{abstract}
Summary. Extratesticular sperm maturation in the echidna mainly occurs in the initial segment of the ductus epididymidis. The process involves the development of motility, migration and loss of the cytoplasmic droplet, a decrease in permeability to Congo red and the formation of sperm bundles. The spermatozoa are supported in the bundles by a matrix of electron-dense material; the bundles are very motile in undiluted samples of luminal fluids.

Micropuncture studies of anaesthetized echidnas showed that the ductuli efferentes absorb $74 \%$ of the fluid and $46 \%$ of the soluble protein that enters them. The initial segment of the ductus epididymidis absorbs $83 \%$ of the fluid which enters it, and its secretions increase the concentration of protein in luminal fluid by $107 \%$. Denatured, linear-gradient polyacrylamide gel electrophoresis of micropuncture samples showed that 1 protein (apparent $M_{r}=100500$ ) which is not present in blood plasma is present in rete testis fluid, and a glycoprotein which is present in rete testis fluid (apparent $\mathbf{M}_{\mathrm{r}}$ $=78500$ ) is absorbed by the ductuli efferentes. Six proteins which are not present in blood plasma are secreted into the initial segment of the ductus epididymidis; 5 are glycoproteins (apparent $M_{r}=48500,39000,32000,20500$ and 19000) and one (apparent $\mathrm{M}_{\mathrm{r}}=82500$ ) is not. The most prominent electrophoresis bands corresponded to the glycoproteins with apparent molecular weights of 48500,20500 and 19000 .
\end{abstract}

\section{Introduction}

It is generally accepted that the mammalian epididymis has three functions other than the transport of spermatozoa: the absorption of most of the fluid leaving the testis (Levine \& Marsh, 1971), sperm maturation (Young, 1931), and the storage of spermatozoa in a quiescent state (Jones, 1973b, 1978; Wyker \& Howards, 1977). However, our knowledge of these functions of the mammalian epididymis is limited to a few laboratory and domestic, scrotal, eutherian mammals, and the African elephant (Jones, Rowlands \& Skinner, 1974; Jones, 1980) in which the testis and epididymis reside deep within the abdominal cavity (Jones \& Brosnan, 1981). Clearly a knowledge of the function of a wider variety of mammals, particularly the monotremes, is essential to assess the function and evolutionary development of the mammalian epididymis.

The echidna (Tachyglossus) is the most wide ranging of the three extant monotremes (Griffiths, 1978) and unlike the platypus it is a heterothermic endotherm. Earlier studies (Jones \& Djakiew, 1978; Djakiew \& Jones, 1981, 1982a, b) confirmed that its testes and epididymides are intraabdominal and that the epididymis is structurally differentiated into only three regions (the ductuli 
efferentes and the initial and terminal segments of the ductus epididymidis) rather than the 7 or more regions that have been described for the eutherian mammals which have been studied (Reid \& Cleland, 1957; Hoffer \& Greenberg, 1978; Nicander \& Ploen, 1979).

This report describes studies of spermatozoa in the epididymis of the echidna which were carried out to assess the occurrence of maturational changes. However, since earlier reports (Bedford \& Rifkin, 1979; Carrick \& Hughes, 1982) have described the ultrastructure of echidna spermatozoa our ultrastructural studies are only mentioned briefly in this report. Fluid absorption by the ductuli efferentes and initial segment of the ductus epididymidis were examined since their individual roles have not been clarified in earlier studies on the epididymis (Levine \& Marsh, 1971; Turner, Hartmann \& Howards, 1977; Hinton, 1979). The absorption and secretion of proteins was examined because proteins have been implicated in the maturation of spermatozoa (Orgebin-Crist \& Jahad, 1978, 1979; Hoskins, Brandt \& Acott, 1978; Lea, Petrusz \& French, 1978) and may be involved in their storage. Further, it is anticipated that, by comparison with work on other species (see Cameo \& Blaquier, 1976; Brooks \& Higgins, 1980; Jones, Brown, von Glos \& Parker, 1980; Jones, von Glos \& Brown, 1981), it may be possible to identify epididymal proteins which may be homologous amongst mammals.

\section{Materials and Methods}

\section{Animals}

Six of the 12 animals used were captured on Kangaroo Island, South Australia, and 6 were captured in the Hunter Valley, New South Wales. Each animal was used for more than one study. The echidna were captured during their mating season (July and August); the epididymal ducts were replete with spermatozoa and histological examination of the testis showed that spermatogenesis was normal.

\section{Sperm maturation}

The motility of spermatozoa was examined in undiluted samples of luminal contents which were collected by micropuncture from the epididymal ducts (see below). The samples were mounted between a microscope slide and coverslip (wet mounts) and examined under a phasecontrast microscope.

The development of sperm motility was also studied. Immediately after slaughter, tissue $\left(\sim 3 \mathrm{~mm}^{3}\right)$ was removed from the sampling sites shown in Text-fig. 1 and placed in $0.2 \mathrm{ml}$ calciumfree Krebs-Ringer phosphate (Umbreit, Burris \& Stauffer, 1972) under $1 \mathrm{ml}$ water-saturated paraffin oil held in embryo dishes at $31^{\circ} \mathrm{C}$. The tissue was minced with scissors and then removed after incubation for 10 min to release the spermatozoa. Wet mounts of the samples were prepared and examined under a phase-contrast microscope (Jones, 1971). The rate of progressive motility was scored on a scale of 0 to 4 and the percentage of motile cells was scored on a scale of 0 to 100 . Congo red-fast green smears of spermatozoa were prepared (Entwistle, 1972), and 100 spermatozoa were examined under the light microscope and scored as stained or unstained by Congo red.

The ultrastructure of spermatozoa in different parts of the epididymis was examined using sections from 3 animals which were prepared for an earlier study (Djakiew \& Jones, 1982a). Scanning electron microscopy was also used to examine the sperm bundles. Epididymal tissue was prepared by pinning small blocks $\left(\sim 3 \mathrm{~mm}^{3}\right)$ to cork and immersing the tissue in $2.5 \%$ glutaraldehyde-cacodylate $\left(\mathrm{pH} \mathrm{7.3)}\right.$ at $5^{\circ} \mathrm{C}$ for $24 \mathrm{~h} \mathrm{(Hafez} \mathrm{et} \mathrm{al.,} \mathrm{1975).} \mathrm{The} \mathrm{tissue} \mathrm{was} \mathrm{subsequently}$ washed, dehydrated in ethanol, substituted with amyl acetate, dried under vacuum (Dynavac FD24, Burwood, N.S.W.) and coated with gold. The preparations were examined in a JEOL JXA $50 \mathrm{~A}$ scanning electron microscope. 


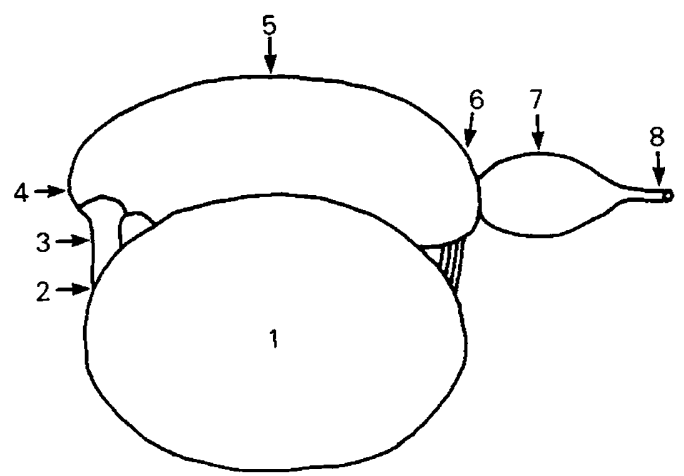

Text-fig. 1. Diagram of a lateral view of the testis and epididymis of the echidna showing the sites used to assess the maturation of spermatozoa $(1,3-8)$ and for collecting micropuncture samples $(2,4,6$ and 7$)$. Site 1 is the testis, site 2 is the rete testis; site 3 is the ductuli efferentes; sites 4,5 and 6 are the proximal, middle and distal ends of the initial segment, respectively; site 7 is the terminal segment of the ductus epididymidis; site 8 is the ductus deferens.

The location of the cytoplasmic droplet on spermatozoa was determined using epididymides previously fixed in formal-saline. Tissue $\left(5 \mathrm{~mm}^{3}\right)$ from each sampling site (Text-fig. 1) was homogenized for $5 \mathrm{~min}$ in a glass homogenizer (Kontes Glass Co., New Jersey, U.S.A.) containing a solution of $100 \mathrm{~mm}$-sodium citrate, $1 \mu \mathrm{l}$ Triton $\mathrm{X}-100 / \mathrm{ml}$ and $1 \%(\mathrm{v} / \mathrm{v})$ formalin. Wet mounts were prepared and 100 spermatozoa were examined under a phase-contrast microscope. The location of the cytoplasmic droplet was scored as being on the head, the proximal, middle or distal end of the middle piece, or absent.

\section{Collection of micropuncture samples}

Glass micropipettes were prepared from constant-bore tubing with an outer diameter of $860 \mu \mathrm{m}$ and wall thickness of $70 \mu \mathrm{m}$. They were pulled on a Narishige PN-3 glass microelectrode puller (Narishige Scientific Instrument Lab., Tokyo) and bevelled on a diamond grinding wheel (Norton, U.S.A.) to produce tip diameters of $30-120 \mu \mathrm{m}$.

The animals were anaesthetized with 5-sec-butyl-5-ethyl-thiobarbituric acid, sodium salt (Inactin: Byk Gulden Pharmaceuticals, Konstanz, West Germany). An intraperitoneal injection of approximately $90 \mathrm{mg} / \mathrm{kg}$ was administered as a number of doses, initially at a dose of $60 \mathrm{mg} / \mathrm{kg}$, then at subsequent doses of $10 \mathrm{mg} / \mathrm{kg}$ every $15 \mathrm{~min}$ until satisfactory anaesthesia was achieved. Animals were supported on a metal heater and their body temperature was monitored by a probe (Model 43 Telethermometer, YS1 Scientific, Ohio, U.S.A.) inserted $8-10 \mathrm{~cm}$ into the rectum. The mean \pm s.e.m. ( 5 animals) body temperature was $29.5 \pm 0.73^{\circ} \mathrm{C}$ just after they were anaesthetized. They were warmed to $31^{\circ} \mathrm{C}$ (Griffiths, 1978) during preparation for micropuncture and were maintained within $0 \cdot 5^{\circ} \mathrm{C}$ of this temperature. The trachea, a jugular vein and a femoral artery were cannulated immediately after anaesthesia. The jugular vein was infused (Model 341A syringe pump; Sage Instruments, Massachussets, U.S.A.) with heparinized saline $(0 \cdot 24 \% \mathrm{w} / \mathrm{v}$ heparin) at the rate of $6.5 \mathrm{ml} / \mathrm{h}$ to maintain body fluids. The cannula in the femoral artery was connected to a mercury U-tube manometer to monitor blood pressure. Haematocrits were prepared at about hourly intervals to monitor blood volume. The mean \pm s.e.m. blood pressure $(94.0 \pm 7.5 \mathrm{mmHg} ; 5$ animals) and haematocrits $(33.3 \pm 1 \cdot 1 \% ; 6$ animals) remained fairly constant during the experimental period.

The abdominal cavity was entered through a midline incision. The left testis and epididymis was isolated and the proximal end of the ductuli efferentes was ligated with a haemoclip (Weck, North Carolina, U.S.A.) to accumulate rete testis fluid for sampling. The right testis and 
epididymis were prepared for micropuncture by supporting them in a cup, manufactured with Araldite (CIBA-Geigy: HY951 and LC191, 1:8 w/w) for the purpose, with wads of cotton wool soaked in warm $\left(31^{\circ} \mathrm{C}\right)$, water-saturated, paraffin oil (Fisher Scientific Co., New Jersey, U.S.A.). The exposed viscera were covered with the oil and during the course of the study the oil was continuously dripped (heater from Institute of Physiology, Munich) onto the reproductive tract.

The micropuncture procedures described by Ullrich, Fromter \& Baumann (1969) were used to collect samples of luminal fluids from 4 sites in the reproductive tract (Text-fig. 1). The procedure was carried out under a Zeiss OMl operating microscope (Carl Zeiss, West Germany) and the micropipettes were inserted using a micromanipulator (Leitz, West Germany).

The samples of luminal fluid were collected in the micropipettes between layers of watersaturated paraffin oil stained with Sudan black. The pipettes were sealed with resin (BDH, U.K.), supported in a haematocrit tube and centrifuged in a microhaematocrit centrifuge (Hawksley, U.K.) for $15 \mathrm{~min}$ at $12000 \mathrm{~g}$ (longer periods did not affect the separation); blood samples collected in heparinized haematocrit tubes were centrifuged concurrently. The percentage volumes of spermatozoa and erythrocytes were estimated as the ratio of length of tubing occupied by the cells : the total length occupied by the sample. The supernatants were collected for analyses of protein and stored at $-20^{\circ} \mathrm{C}$ between layers of water-saturated, paraffin oil.

\section{Electron microscopy of luminal contents}

Samples collected by micropuncture were fixed by immersion in PFG-cacodylate (Jones, 1973a), and then osmicated, dehydrated in ethanol and embedded in Araldite. Thin sections with silver and pale gold interference colours were stained with aqueous uranyl acetate (Watson, 1958) and lead citrate (Reynolds, 1963) and examined under a JEOL 100CX transmission electron microscope. The sections used by Djakiew \& Jones (1982a) were used to examine the luminal contents in situ.

\section{Analysis of proteins}

Quantitative analysis was carried out by the procedure of Bradford (1976) using bovine serum albumin as the standard. Electrophoresis was performed by the sodium dodecyl sulphate (SDS) linear gradient polyacrylamide gel system developed by Matsudaira \& Burgess (1978). The SDSTris glycine gel formulations of Laemmli (1970) were used (except that $0.3 \%$ rather than $0.8 \% N, N^{\prime}-$ methylene-bis-acrylamide was used) to form a 10-20\% linear gradient separation gel. Bromophenol blue $(0.004 \% \mathrm{w} / \mathrm{v})$ was added to the $10 \%$ acrylamide solution and after polymerization the linearity of the gradient was confirmed by densitometry ( $R$ \& $D$ Quick Scan densitometer: Helena Laboratories, Texas, U.S.A.). Volumes of the micropuncture samples, and molecular weight calibration proteins (Pharmacia, Sweden) which contained $10 \mu \mathrm{g}$ protein were mixed in the ratio $2: 1$ with the solubilizing buffer. The latter contained $40 \%(\mathrm{v} / \mathrm{v})$ stacking buffer (Laemmli, 1970), $28 \%(\mathrm{v} / \mathrm{v})$ glycerol, $12 \%(\mathrm{v} / \mathrm{v}) \beta$-mercaptoethanol, $8 \%(\mathrm{w} / \mathrm{v})$ SDS and $0.01 \%(\mathrm{w} / \mathrm{v})$ bromophenol blue. The gels were stained with Coomassie Brilliant Blue R250 (Sigma, U.S.A.) or periodic acidSchiff (Fairbanks, Steck \& Wallach, 1971). Stained gels were scanned on the densitometer and the mobilities of proteins were calculated relative to the trailing edge of the ion front. Estimates of apparent molecular weight were determined from graphs of relative mobility versus $\log$ of molecular weight.

\section{Analysis of data}

When appropriate data were examined using analyses of variance. The standard errors shown in Table 1 were calculated from the residual errors. However, values in Tables $2-4$ were calculated from the variances between animals. 


\section{Results}

\section{Sperm maturation}

Spermatozoa were immotile in freshly collected undiluted samples of luminal fluid from the rete testis and initial segment of the ductus epididymidis. However, the bundles of spermatozoa present in the terminal segment of the ductus epididymidis (see Djakiew \& Jones, 1981) were highly motile as they entered the micropuncture pipette.

When the spermatozoa were diluted in Krebs-Ringer phosphate (Table 1), testicular spermatozoa remained immotile, but motility developed during passage through the initial segment of the ductus epididymidis ( $P<0.001$ and $P<0.01$ for scores of rate and $\%$ motile respectively). No change in the pattern of motility was observed in spermatozoa from different parts of the initial segment. However, there was an increase $(P<0.05)$ in the mean scores of rate of motility between samples from the distal initial segment (individual spermatozoa) and the terminal segment (spermatozoa in bundles). In the latter samples a comparison of spermatozoa that occurred individually (a low proportion) with those that were in bundles indicated that the former progressed at about the same velocity as spermatozoa from the distal initial segment, i.e. slower than the bundles of spermatozoa.

Table 1. Mean scores of rate of progressive motility and percentage motile, and counts of percentage unstained spermatozoa from the testis, epididymis and ductus deferens of echidna (means from 3 animals)

\begin{tabular}{llcc}
\hline & \multicolumn{2}{c}{ Motility } & \\
\cline { 2 - 3 } \multicolumn{1}{c}{ Site } & Rate & $\%$ & Unstained \\
\hline Testis & $0^{*}$ & $0^{*}$ & $28 \cdot 7$ \\
Ductuli efferentes & 0.67 & 10 & $28 \cdot 3$ \\
Ductus epididymidis & & & \\
$\quad$ Initial segment & 1.00 & 43 & $37 \cdot 7$ \\
$\quad$ Proximal & 1.67 & 67 & $59 \cdot 3$ \\
$\quad$ Middle & $2 \cdot 00$ & 70 & $84 \cdot 7$ \\
$\quad$ Distal & $4 \cdot 00$ & 80 & $91 \cdot 0$ \\
Terminal segment & $2 \cdot 67$ & 60 & $87 \cdot 7$ \\
Ductus deferens & \pm 0.22 & $\pm 11 \cdot 7$ & \pm 4.8 \\
\hline s.e.m. & &
\end{tabular}

* Data not used to calculate s.e.m.

Table 2. The occurrence $(\%)$ of the cytoplasmic droplet on various parts of spermatozoa from the testis, epididymis and ductus deferens of echidna (means \pm s.e.m. from 4 animals)

\begin{tabular}{|c|c|c|c|c|c|}
\hline \multirow[b]{2}{*}{ Site } & \multirow[b]{2}{*}{ Head } & \multicolumn{3}{|c|}{ Middle piece } & \multirow[b]{2}{*}{ Absent } \\
\hline & & Proximal & Middle & Distal & \\
\hline Testis & $85 \cdot 5 \pm 1 \cdot 7$ & 0 & 0 & 0 & $14 \cdot 5 \pm 1 \cdot 7$ \\
\hline Ductuli efferentes & $86.5 \pm 2.9$ & 0 & 0 & 0 & $13 \cdot 5 \pm 2 \cdot 9$ \\
\hline \multicolumn{6}{|l|}{ Ductus epididymidis } \\
\hline \multicolumn{6}{|l|}{ Initial segment } \\
\hline Proximal & $83 \cdot 5 \pm 1 \cdot 2$ & $2 \cdot 5 \pm 1 \cdot 1$ & 0 & 0 & $14 \cdot 0 \pm 1 \cdot 5$ \\
\hline Middle & $0.8 \pm 0.8$ & $8.7 \pm 2.8$ & $35 \cdot 2 \pm 1 \cdot 5$ & $26 \cdot 0 \pm 2 \cdot 5$ & $29 \cdot 3 \pm 2 \cdot 0$ \\
\hline Distal & 0 & $\overline{0}$ & $0.5 \pm 0.5$ & $9 \cdot 5 \pm 3 \cdot 2$ & $90 \cdot 0 \pm 3 \cdot 1$ \\
\hline Terminal segment & 0 & 0 & $\overline{0}$ & 0 & 100 \\
\hline Ductus deferens & 0 & 0 & 0 & $\mathbf{0}$ & 100 \\
\hline
\end{tabular}


The percentage of unstained spermatozoa also increased along the initial segment $(P<0.001)$, but showed little change beyond this region (Table 1).

The cytoplasmic droplet was located around the head of most spermatozoa collected from the testis and ductuli efferentes (Table 2). The droplet migrated distally, and then was lost during the passage of spermatozoa through the initial segment. No other structural changes occurred to spermatozoa during passage through the epididymis. The sperm bundles in the terminal segment consisted of more than 100 spermatozoa wrapped around one another in a helical fashion (Pl. 1, Fig. 1). The spermatozoa in these bundles were bound together by electron-dense material (P1. 2, Figs $2 \& 3$ ). This was most electron-dense at the apex of a bundle, and immediately around the acrosome where it appeared to form aggregates; however, a less electron-dense material appeared to form the main matrix which held the spermatozoa together.

\section{Spermatocrits}

Centrifugation of the micropuncture samples from the ductus epididymidis resulted in the formation of a translucent layer between the bottom layer which contained spermatozoa and the top clear layer. The upper boundary of the translucent layer was ill-defined, but it was estimated that the layer formed $2 \cdot 0 \pm 0.4 \%$ and $12 \cdot 4 \pm 1 \cdot 3 \%$ of the total volume of samples from the proximal and distal ends of the initial segment, respectively, and it formed $13 \cdot 1 \pm 1.8 \%$ of the samples from the terminal segment.

Phase-contrast microscopy showed that the translucent layer was composed of very small flocculent material. Electron microscopy showed that the translucent layer consisted of non-sperm particulate matter present in the lumen of the ductus epididymidis (see Fig. 9, Djakiew \& Jones, 1982a): at the proximal end of the initial segment this mainly consisted of flocculent electron-dense material secreted by the epithelium, and an occasional fragment of cell debris reminiscent of germ cells. Cytoplasmic droplets were also present at the distal end of the initial segment, and membranous material reminiscent of degenerate apocrine secretions was present in samples from the terminal segment.

Spermatocrit values (Table 3) were very low for the rete testis fluid but increased between the rete testis and the proximal initial segment of the ductus epididymidis $(P<0.01)$, indicating that there was a net absorption by the ductuli efferentes of $74 \%$ of the fluid leaving the testis. There was a further increase in spermatocrit between samples from the proximal and distal ends of the initial segment $(P<0.001)$. This increase corresponds to a net absorption by the initial segment of $83 \%$ of the fluid entering the segment, or $22 \%$ of the fluid leaving the testis. Using the spermatocrit value for the terminal segment it was estimated that there was a net absorption by the epididymis of $95 \%$ of the fluid leaving the testis.

\section{PLATE 1}

Fig. 1. Scanning electron micrograph of bundles of echidna spermatozoa in the terminal segment of the ductus epididymidis showing how the spermatozoa are wrapped around one another in a helical manner and appear to be bound together for much of their length. $\times 2900$.

\section{PLATE 2}

Fig. 2. A transmission electron micrograph of a sagittal section through a bundle of spermatozoa in the terminal segment of the ductus epididymidis. The arrow indicates the distal extent of the acrosome. Note the electron-dense material (D) which forms at the apex of the bundle, and the main matrix $(M)$ between the spermatozoa. $\times 10300$.

Fig. 3. A transmission electron micrograph of a cross-section through the acrosome (A) of a spermatozoon. The periacrosomal plasmalemma is covered with discrete aggregates of flocculent electron-dense material. $\times 112400$. 


\section{PLATE}

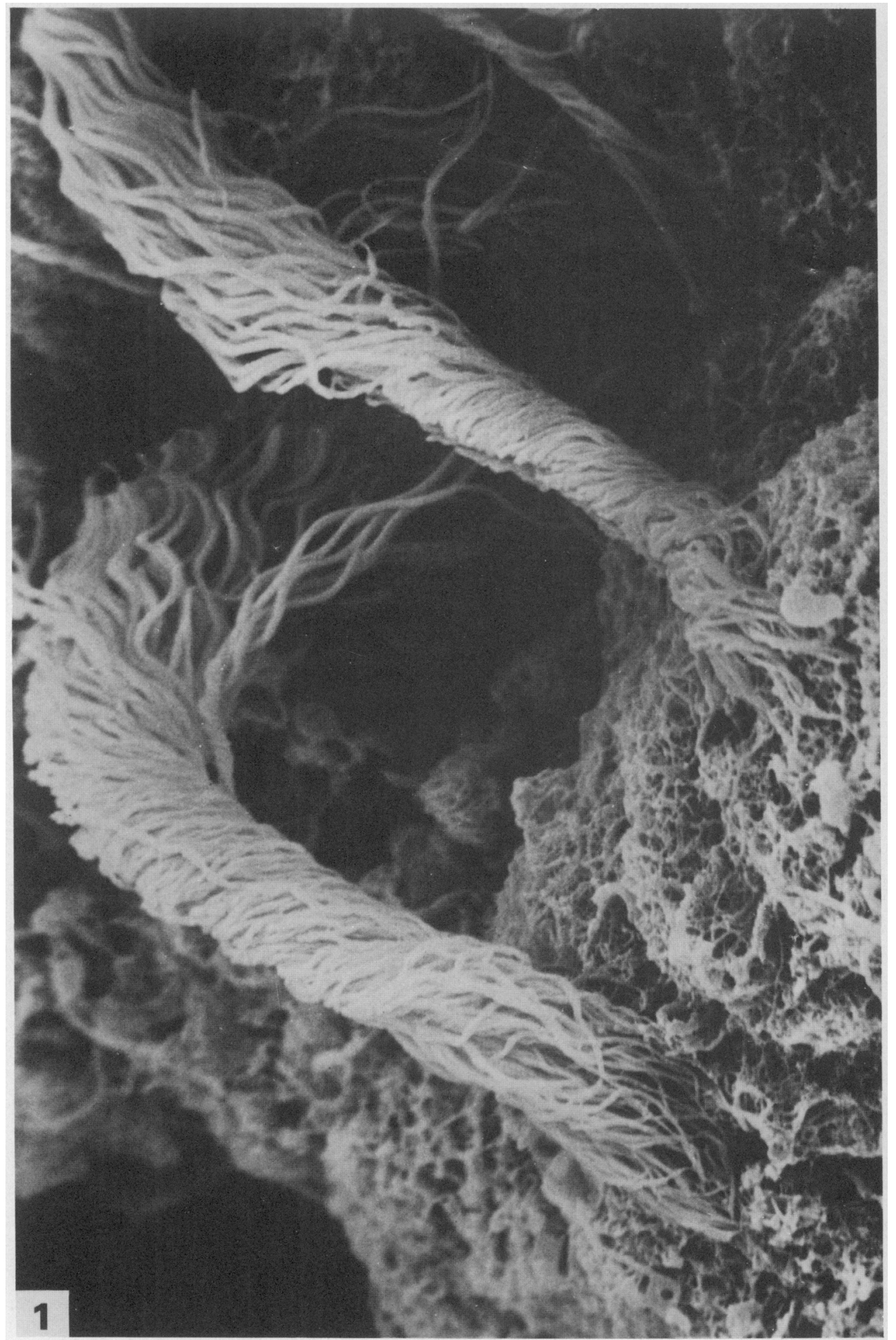

(Facing p. 450) 
PLATE 2

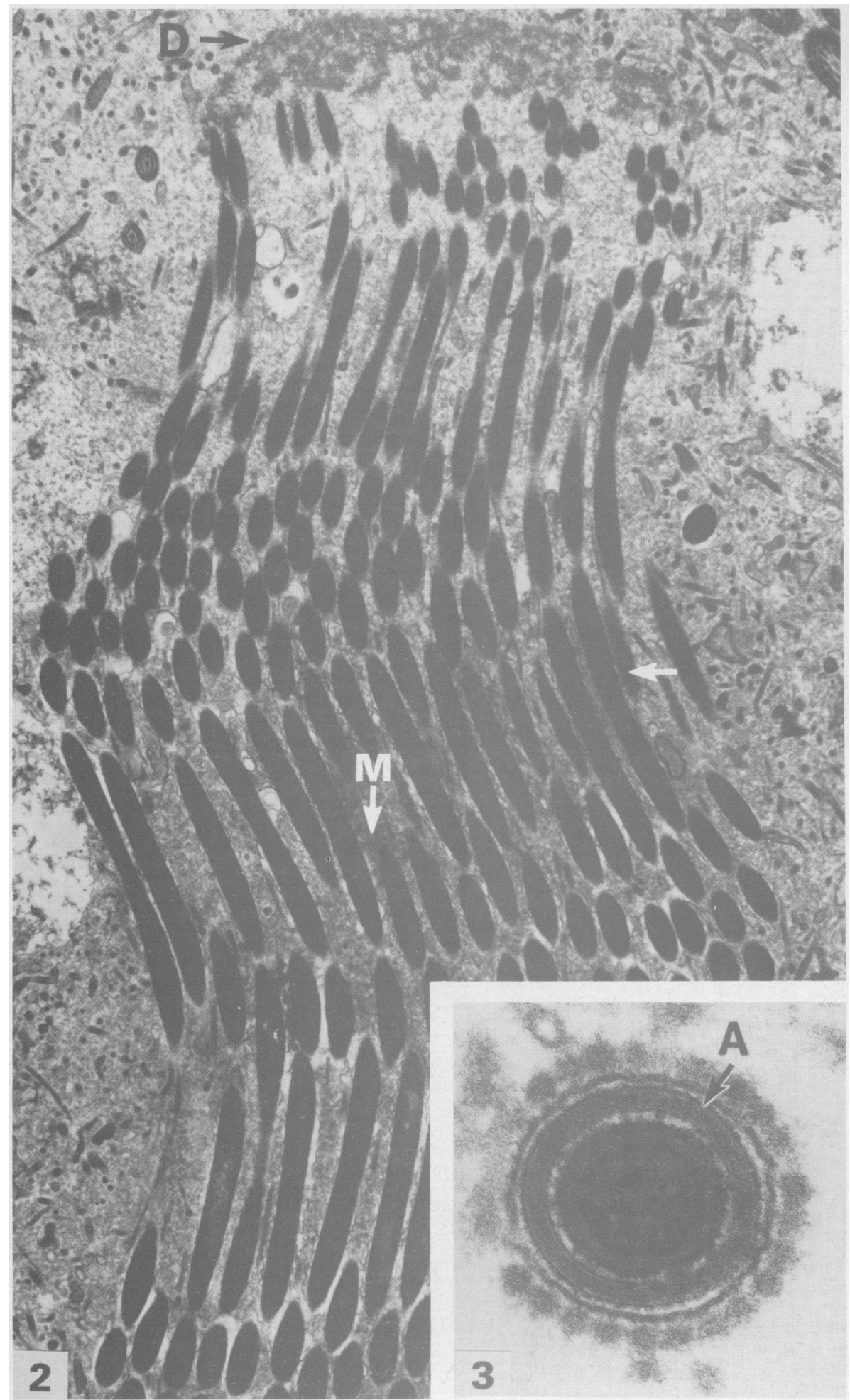


Table 3. Composition of luminal fluid from the rete testis and ductus epididymidis of echidna (means \pm s.e.m. for 6 animals)

\begin{tabular}{|c|c|c|c|c|}
\hline & Spermatocrit & $\begin{array}{c}\text { Absorption } \\
\text { of fluid } \\
(\%)^{*}\end{array}$ & $\begin{array}{l}\text { Protein } \\
(\mu \mathrm{g} / \mu \mathrm{l})\end{array}$ & $\begin{array}{l}\text { Absorption } \\
\text { of protein } \\
(\%)^{*}\end{array}$ \\
\hline $\begin{array}{l}\text { Rete testis } \\
\text { Ductus epididymidis }\end{array}$ & $1.52 \pm 0.27$ & - & $2 \cdot 35 \pm 0 \cdot 52$ & - \\
\hline Proximal initial segment & $5.82+1.08^{b}$ & 73.88 & $4.94+0.65^{a}$ & $45 \cdot 53$ \\
\hline Distal initial segment & $33.43 \pm 2.08^{c}$ & 82.59 & $58.80 \pm 3.66^{\circ}$ & $-107 \cdot 29$ \\
\hline Terminal segment & $31.63 \pm 1.54$ & $-5 \cdot 69$ & $39 \cdot 84 \pm 1 \cdot 70^{c}$ & $28 \cdot 38$ \\
\hline
\end{tabular}

Values significantly different from the mean for the more proximal site ${ }^{\mathrm{a}} P<0.05$; ${ }^{\mathrm{b}} P<0.01$; ${ }^{\mathrm{c} P}<0.001$.

* Percentage absorption calculated relative to more proximal site.

\section{Protein}

It was not possible to separate satisfactorily the two supernatant layers after centrifuging the micropuncture samples so they were collected together for the analyses of protein.

The mean \pm s.e.m. concentration of protein in blood plasma $(55.89 \pm 2.44 \mu \mathrm{g} / \mu \mathrm{l})$ was higher $(P$ $<0.01$ ) than for any of the samples from the reproductive tract, except for those from the distal site in the initial segment of the ductus epididymidis (Table 3 ).

The protein concentration was very low in samples from the rete testis and was about twice this value in samples from the proximal site in the initial segment of the ductus epididymidis. However,

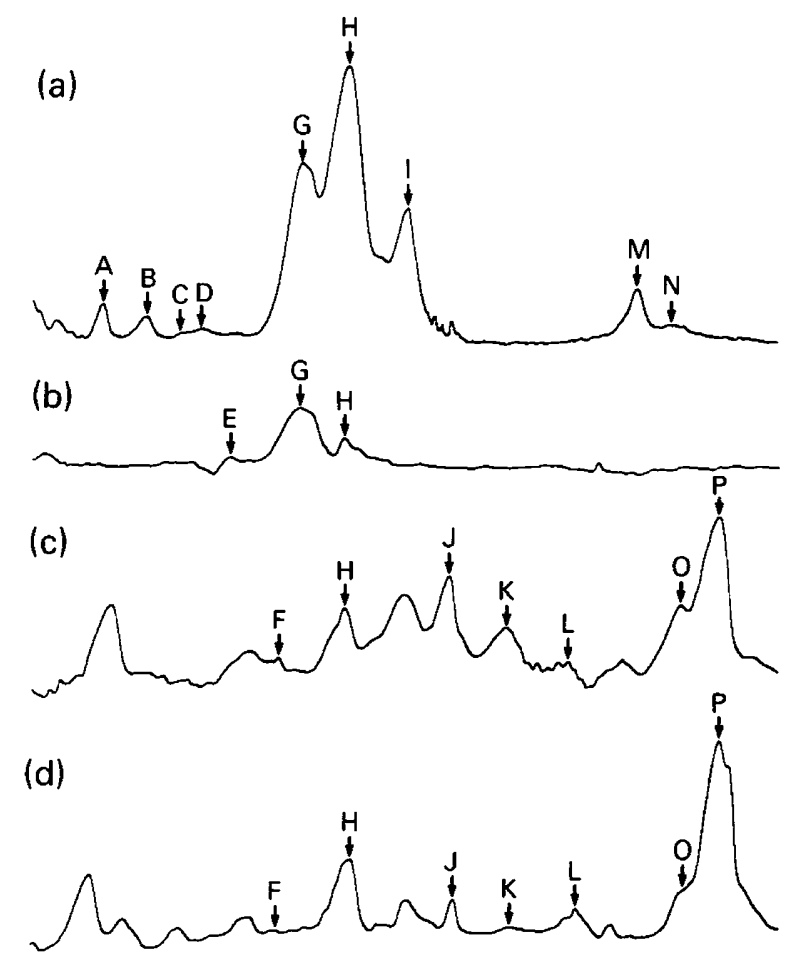

Text-fig. 2. Densitometer tracings of polyacrylamide gels stained with Coomassie blue of (a) blood plasma, (b) rete testis fluid, and fluid from the (c) initial and (d) terminal segments of the ductus epididymidis. A-P correspond to the identifications shown in Table 4; band $\mathrm{H}$, which corresponds to albumin, is shown on all traces; band $E$ is present in (b), (c) and (d); band $G$ is present in (a) and (b); and bands F, J, K, L, O and P are specific to (c) and (d). 
after accounting for the concentrating effect of fluid absorption in the ductuli efferentes it was estimated that the ductuli were involved in a net absorption of at least $46 \%$ of the soluble protein leaving the testis. In this context, the increase in protein concentration along the initial segment corresponds to a net increase of $107 \%$, and the reduction in protein content between the initial and terminal segments corresponds to a net loss of $28 \%$ of the soluble protein.

Densitometer tracings of electrophoresis gels for samples of blood plasma and reproductive fluids are shown in Text-fig. 2 (a tracing for samples from the proximal end of the initial segment is not shown since it was qualitatively similar to the tracing for samples from the distal end of the initial segment, Text-fig. 2c). The apparent molecular weights of the proteins are summarized in Table 4. All of the samples formed a heavy band for albumin corresponding to a mean apparent molecular weight of 63500-69500. The range of estimates of apparent molecular weights of this protein was probably due to different degrees of interference with inorganic ions or other proteins (Gower \& Rodnight, 1982). Blood plasma formed 9 electrophoretic bands whilst rete testis fluid formed 4; only one of the bands in rete testis fluid (Text-fig. 2b, band E) did not correspond to a band formed by blood plasma. The absence in samples from the ductus epididymidis (Text-figs $2 \mathrm{c}$ $\&$ d) of one of the bands formed by rete testis fluid (band $G$ ) indicates that the protein corresponding to band $\mathrm{G}$ was selectively absorbed in the ductuli efferentes. Of the 13 bands formed by samples from the initial segment (Text-fig. 2c), 6 correspond to bands formed by blood plasma (bands A, B, C, H, I \& M), 2 correspond to bands formed by blood plasma and rete testis fluid (bands $\mathrm{H} \& \mathrm{I}$ ), 1 corresponds to the band specific for rete testis fluid (band $\mathrm{E}$ ), and 6 are specific to the ductus epididymidis (bands F, J, K, L, O \& P). Bands $J$ and $O$, and particularly $P$, were the most prominent bands formed by the epididymal fluids; they correspond to glycoproteins with apparent molecular weights of 48500,20500 and 19000 respectively. The electrophoresis patterns were similar for samples from the initial and terminal segments of the ductus epididymidis indicating that in the terminal segment there was no qualitative loss or gain of specific proteins.

Table 4. Estimates of apparent molecular weights $\left(\times 10^{3}\right)$ for each of the protein bands in the SDSpolyacrylamide gels of blood plasma and luminal fluids from the rete testis, and initial and terminal segments of the ductus epididymidis of echidna (means \pm s.e.m. for samples from 6 animals)

\begin{tabular}{|c|c|c|c|c|}
\hline & Blood plasma & Rete testis & Initial segment & Terminal segment \\
\hline$A^{*}$ & $154 \cdot 0 \pm 6 \cdot 0$ & - & $154 \cdot 0 \pm 4 \cdot 0$ & $148 \cdot 0 \pm 6 \cdot 0$ \\
\hline B & $132.5 \pm 3.5$ & - & $131.5 \pm 3.5$ & $131 \cdot 5 \pm 4.0$ \\
\hline $\mathrm{C}^{*}$ & $119.0 \pm 3.5$ & - & $114.5 \pm 5.0$ & $115.5 \pm 3.0$ \\
\hline D & $100 \cdot 0 \pm 3.5$ & - & - & - \\
\hline $\mathrm{E}$ & - & $100 \cdot 5 \pm 3 \cdot 0$ & $96 \cdot 5 \pm 3 \cdot 5$ & $95 \cdot 0 \pm 1 \cdot 5$ \\
\hline $\mathrm{F}$ & - & - & $82 \cdot 5 \pm 3 \cdot 5$ & $82 \cdot 0 \pm 1.5$ \\
\hline $\mathrm{G}^{*}$ & $76 \cdot 5+2 \cdot 5$ & $78 \cdot 5+2 \cdot 0$ & - & - \\
\hline $\mathbf{H}$ & $68 \cdot 0 \pm 2 \cdot 0$ & $63.5 \pm 1.0$ & $67.5 \pm 3.0$ & $69 \cdot 5 \pm 2 \cdot 0$ \\
\hline$I^{*}$ & $57.5 \pm 2.0$ & $53 \cdot 5 \pm 2.5$ & $56.5 \pm 1.5$ & $57 \cdot 0 \pm 1 \cdot 5$ \\
\hline $\mathrm{J}^{*}$ & - & - & $48 \cdot 5 \pm 2 \cdot 5$ & $50 \cdot 0 \pm 1 \cdot 5$ \\
\hline $\mathrm{K}^{*}$ & - & - & $39 \cdot 0 \pm 1.5$ & $38.5 \pm 1 \cdot 5$ \\
\hline $\mathbf{L}^{*}$ & - & - & $32 \cdot 0 \pm 1 \cdot 0$ & $31.0 \pm 0.5$ \\
\hline $\mathbf{M}$ & $26 \cdot 5 \pm 0.5$ & $\ldots$ & $27 \cdot 5 \pm 1 \cdot 0$ & $27 \cdot 0 \pm 1 \cdot 0$ \\
\hline $\mathrm{N}$ & $23.5 \pm 0.5$ & - & - & - \\
\hline $\mathrm{O}^{*}$ & - & - & $20.5 \pm 0.5$ & $19 \cdot 5 \pm 0.5$ \\
\hline $\mathrm{P}^{*}$ & - & - & $19 \cdot 0 \pm 0.5$ & $18 \cdot 5 \pm 0.5$ \\
\hline
\end{tabular}

* PAS-positive proteins.

\section{Discussion}

Probably the most noteworthy feature of sperm maturation in the epididymis of the echidna is that the process is virtually complete within the initial segment. The process involves the main events which have been described for eutherian mammals, i.e. the development of motility, change in the 
location of the cytoplasmic droplet and a decreased permeability of the plasmalemma (Branton \& Salisbury, 1947; Glover, 1962; Gaddum, 1968; Jones, 1971, 1980; Jones et al., 1974; Cummins, 1976; Temple-Smith \& Bedford, 1976).

The development of motility by echidna spermatozoa differs from the process described in eutherian mammals in that no change in the pattern of motility was detected in individual echidna spermatozoa. This could be due to difficulties of detecting such a change in spermatozoa with a helical structure (Benda, 1906; Bedford \& Rifkin, 1979; Carrick \& Hughes, 1982). Nevertheless, the formation of sperm bundles is associated with an increase in velocity which may be analogous to a change in the pattern of motility.

Although echidna spermatozoa are similar to those of eutherian mammals in that there is some change in the location and ultimate loss of the cytoplasmic droplet, there are some dissimilarities. In the echidna the proximal location of the cytoplasmic droplet is around the head of the spermatozoon; it migrates to the distal end of the middle piece and is discarded into the epididymal lumen. In marsupials the droplet is initially located around the head and neck, but then it condenses to the neck and is discarded into the epididymal lumen (Temple-Smith \& Bedford, 1976, 1980). In eutherians the droplet is initially located in the neck region; it migrates to the distal end of the middle piece during epididymal transport, but is not discarded until ejaculation (Branton \& Salisbury, 1947; White \& Wales, 1961).

The formation of sperm bundles in the echidna differs from the rouleaux formation in the guinea-pig (Fawcett \& Hollenberg, 1963) and flying squirrel (Martan \& Hruban, 1970), and the pairing of spermatozoa in American marsupials (Biggers, Creed \& De Lameter, 1963; TempleSmith \& Bedford, 1980). The cellular association in eutherian spermatozoa seems to involve binding of adjacent membranes whereas in the echidna the process is preceded by shedding of the cytoplasmic droplet, and the association involves a matrix of electron-dense material which binds the spermatozoa together. Moreover, the echidna spermatozoa are twisted around one another rather than just stacked together.

The studies described in this report demonstrate that, as in the African elephant (Jones, 1980), the ductuli efferentes are responsible for the absorption of most of the fluid leaving the testis. The ductuli also absorb nearly half of the protein leaving the testis, and concentrate the remainder in the Iuminal fluid (Jones, 1980). The demonstration that a specific protein is absorbed is in agreement with ultrastructural studies on other mammals which show that bristle-coated vesicles are involved in the uptake of luminal fluids during heterophagic digestion by the epithelium lining the ductuli (Sedar, 1966; Flickinger, Howards \& English, 1978; Jones \& Holt, 1981). This finding is also in agreement with the work of Koskimies \& Kormano (1975) which showed that a number of specific proteins present in the rete testis fluid of the rat are absorbed by the caput epididymidis.

The role of the initial segment of the ductus epididymidis in the absorption of fluid is also demonstrated in this report. Nevertheless, it is doubtful whether this segment would play such a large role in fluid absorption in mammals like the rat because, relative to body size, the initial segment is much shorter in the rat than in the echidna (Djakiew \& Jones, 1982b). Protein secretion is obviously a major function of the initial segment in the echidna, and this segment seems to be the only part of the ductus epididymidis which is involved in the secretion of soluble proteins. In the rat and rabbit, only 1 or 2 proteins are secreted by the initial segment; most proteins are secreted in the more distal segments (Brooks \& Higgins, 1980; Jones et al., 1980, 1981).

Djakiew \& Jones (1981) considered that the terminal segment of the ductus epididymidis of the echidna is involved in the storage of spermatozoa available for ejaculation. However, spermatozoa are stored more dilute in the terminal segment of the echidna than in the analogous region in other mammals which have been studied (i.e. spermatocrit of $32 \%$ for the echidna compared with approximately $56 \%$ for the rat (Levine \& Marsh, 1971; Hinton \& Setchell, 1980), 50\% for the elephant (Jones, 1980), and 54\% for the bull (Crabo, 1965). The considerable activity of echidna spermatozoa collected into micropipettes from the terminal segment indicates that their life in situ may be quite short. 
These studies show a similar electrophoretic pattern for luminal fluids from the initial and terminal segments, and that the concentration of soluble protein is lower in the terminal than in the initial segment. It is therefore concluded that the terminal segment of the echidna epididymis probably does not secrete soluble protein. Since ultrastructural studies of the epithelium lining the terminal segment indicate that it is not involved in heterophagic digestion (Djakiew \& Jones, 1982a) it must be assumed that the reduction in protein concentration between the initial and terminal segments is due to the adsorption or incorporation of protein by membranes. The formation of bundles of spermatozoa as they enter the terminal segment indicates that the protein may be involved in that process.

The findings described in this report are encouraging in indicating that it may be possible to identify homologous proteins secreted by the mammalian epididymis. In this context, the protein corresponding to band $\mathrm{K}$ in this study is in the same molecular weight range as the forward motility protein (Hoskins et al., 1978) which probably corresponds to a protein of approximately 37000 in the rat (Olson \& Hamilton, 1978), chimpanzee (Olson \& Gould, 1981) and hamster (Gonzaléz Echeverría, Cuasnicú \& Blaquier, 1982). The proteins corresponding to bands $\mathrm{O}$ and $\mathrm{P}$ are in the same molecular weight range as two glycoproteins in the rat (Brooks \& Higgins, 1980; Jones et al., 1980), and rabbit (Jones et al., 1981), and one glycoprotein in the chimpanzee (Olson \& Gould, 1981) and hamster (Gonzaléz Echeverría et al., 1982).

We thank Dr S. L. Carney and Dr A. H. B. Gillies, Faculty of Medicine, University of Newcastle, for help with the micropuncture procedures; Dr P. R. Dunkley, Faculty of Medicine, University of Newcastle, for help with the electrophoresis; Dr M. Griffiths and $\mathrm{Mr} \mathrm{K}$. W. Newgrain, Division of Wildlife Research, C.S.I.R.O., for discussions and help in collecting echidna; the National Parks and Wildlife Services of New South Wales and South Australia for providing licences for obtaining echidna; and the Australian Research Grants Scheme for financial support.

\section{References}

Bedford, J.M. \& Rifkin, J.M. (1979) An evolutionary view of the male reproductive tract and sperm maturation in a monotreme mammal the echidna, Tachyglossus aculeatus. Am. J. Anat. 156, 207-230.

Benda, C. (1906) Die spermiogenese der monotremen. Denkschr. med.-naturw. Ges. Jena 6, 413-418.

Biggers, J.D., Creed, R.F.S. \& De Lameter, E.D. (1963) Conjugated spermatozoa in American marsupials. $J$. Reprod. Fert. 6, 324, Abstr.

Bradford, M.M. (1976) A rapid and sensitive method for the quantitation of microgram quantities of protein utilizing the principle of protein-dye binding. Analyt. Biochem. 72, 248-254.

Branton, C. \& Salisbury, G.W. (1947) Morphology of spermatozoa from different levels of the reproductive tract of the bull. J. Anim. Sci. 6, 154-160.

Brooks, D.E. \& Higgins, S.J. (1980) Characterization and androgen dependence of proteins associated with luminal fluid and spermatozoa in the rat epididymis. J. Reprod. Fert. 59, 363-375.

Cameo, M.S. \& Blaquier, J.A. (1976) Androgen-controlled specific proteins in rat epididymis. Endocrinology 69, 47-55.

Carrick, F.N. \& Hughes, R.L. (1982) Aspects of the structure and development of monotreme spermatozoa and their relevance to the evolution of mammalian sperm morphology. Cell Tiss. Res. 222, 127-141.
Crabo, B. (1965) Studies on the composition of epididymal contents in bulls and boars. Acta vet scand. 6, Suppl. 5, 1-94.

Cummins, J.M. (1976) Epididymal maturation of spermatozoa in the marsupial Trichosurus vulpecula: changes in motility and gross morphology. Aust. J. Zool. 24, 499-511.

Djakiew, D. \& Jones, R.C. (1981) Structural differentiation of the male genital ducts of the echidna (Tachyglossus aculeatus). J. Anat. 132, 187-202.

Djakiew, D. \& Jones, R.C. (1982a) Ultrastructure of the ductus epididymidis of the echidna, Tachyglossus aculeatus. J. Anat. 135, 625-634.

Djakiew, D. \& Jones, R.C. (1982b) Stereological analysis of the epididymis of the echidna Tachyglossus aculeatus and Wistar rat. Aust. J. Zool. 30, 865875.

Entwistle, K. W. (1972) Congo red-fast green FCF as a supra-vital stain for ram and bull spermatozoa. Aust. vet. J. 48, 515-519.

Fairbanks, G., Steck, T.L. \& Wallach, D.F.H. (1971) Electrophoretic analysis of the major polypeptides of the human erythrocyte membrane. Biochemistry, N.Y. 10, 2606-2617.

Fawcett, D.W. \& Hollenberg, R.D. (1963) Changes in the acrosome of guinea pig spermatozoa during passage through the epididymis. Cell Tiss. Res. 60, 276-292. 
Flickinger, C.J., Howards, S.S. \& English, H.F. (1978) Ultrastructural differences in efferent ducts and several regions of the epididymis of the hamster. $\mathrm{Am}$. J. Anat. 152, 557-586.

Gaddum, P. (1968) Sperm maturation in the male reproductive tract: development of motility. Anat. Rec. 161, 471-482.

Glover, T.D. (1962) The reaction of rabbit spermatozoa to nigrosin eosin following ligation of the epididymis. Int. J. Fert. 7, 1-10.

Gonzaléz Echeverría, F.M., Cuasnicú, P.S. \& Blaquier, J.A. (1982) Identification of androgen-dependent glycoproteins in the hamster epididymis and their association with spermatozoa. J. Reprod. Fert. 64, 17.

Gower, H. \& Rodnight, R. (1982) Intrinsic protein phosphorylation in synaptic plasma membrane fragments from the rat: general characteristics and migration behaviour on polyacrylamide gels of the main phosphate acceptors. Biochim. Biophys. Acta 716, $45-52$.

Griffiths, M. (1978) The Biology of the Monotremes. Academic Press, New York.

Hafez, E.S.E., Barhnart, M.I., Ludwig, H., Lusher, J., Joelsson, I., Daniel, J.L., Sherman, A.I., Jordan, J.A., Wolf, H., Stewart, W.C. \& Chretien, F.C. (1975) Scanning electron microscopy of human reproductive physiology. Acta obstet. gynec. scand., Suppl. 40, $1-61$

Hinton, B.T. (1979) The composition and movement of luminal fluid in the testis and epididymis. Ph.D. thesis, University of Cambridge.

Hinton, B.T. \& Setchell, B.P. (1980) Concentrations of glycerophosphocholine, phosphocholine and free inorganic phosphate in the luminal fluid of the rat testis and epididymis. J. Reprod. Fert. 58, 401-406.

Hoffer, A.P. \& Greenberg, J. (1978) The structure of the epididymis, efferent ductules and ductus deferens of the guinea-pig: a light microscope study. Anat. Rec. 190, 659-676.

Hoskins, D.D., Brandt, H. \& Acott, T.S. (1978) Initiation of sperm motility in the mammalian epididymis. Fedn Proc. Fedn Am. Socs exp. Biol. 37, 2534 2542.

Jones, R., Brown, C.R., von Glos, K.I. \& Parker, M.G. (1980) Hormonal regulation of protein synthesis in the rat epididymis. Characterization of androgendependent and testicular fluid dependent proteins. Biochem. J. 188, 667-676.

Jones, R., von Glos, K.I. \& Brown, C.R. (1981) Characterization of hormonally regulated secretory proteins from the caput epididymidis of the rabbit. Biochem. J: 196, 105-114.

Jones, R.C. (1971) Studies on the structure of the head of boar spermatozoa from the epididymis. J. Reprod. Fert., Suppl. 13, 57-64.

Jones, R.C. (1973a) Preparation of spermatozoa for electron and light microscopy. J. Reprod. Fert. 33, 145-149.

Jones, R.C. (1973b) Collection, motility and storage of spermatozoa from the African elephant, Loxodonta africana. Nature, Lond. 243, 38-39.

Jones, R.C. (1978) Studies on handling spermatozoa from the African elephant, Loxodonta africana. Symp. zool. Soc. Lond. 43, 261-269.
Jones, R.C. (1980) Luminal composition and maturation of spermatozoa in the genital ducts of the African elephant (Loxodonta africana). J. Reprod. Fert. 60, 87-93.

Jones, R.C. \& Brosnan, M.F. (1981) Studies of the deferent ducts from the testis of the African elephant, Loxodonta africana. I. Structural differentiation. $J$. Anat. 132, 371-386.

Jones, R.C. \& Djakiew, D. (1978) The role of the excurrent ducts from the testes of testicond mammals. Aust. Zool. 20, 201-210.

Jones, R.C. \& Holt, W.V. (1981) Studies of the deferent ducts from the testis of the African elephant, Loxodonta africana. III. Ultrastructure and cytochemistry of the ductuli efferentes. J. Anat. 133, 247255.

Jones, R.C., Rowlands, I.W. \& Skinner, J.D. (1974) Spermatozoa in the genital ducts of the African elephant, Loxodonta africana. J. Reprod. Fert. 41, $189-192$.

Koskimies, A.I. \& Kormano, M. (1975) Proteins in fluids from different segments of the rat epididymis. $J$. Reprod. Fert. 43, 345-348.

Laemmli, U.K. (1970) Cleavage of structural proteins during the assembly of the head of bacteriophage T4. Nature, Lond. 227, 680-685.

Lea, O.A., Petrusz, P. \& French, F.S. (1978) Purification and localization of acidic epididymal glycoprotein (AEG): a sperm coating protein secreted by the rat epididymis. Int. J. Androl., Suppl. 2, 592-607.

Levine, N. \& Marsh, D.J. (1971) Micropuncture studies of the electrochemical aspects of fluid and electrolyte transport in individual seminiferous tubules, the epididymis and vas deferens in rats. J. Physiol, Lond. 213, 557-570.

Martan, J. \& Hruban, Z. (1970) Unusual spermatozoon formations in the epididymis of the flying squirrel (Glaucomys volans). J. Reprod. Fert. 21, 167-170.

Matsudaira, P.T. \& Burgess, D.R. (1978) SDS microslab linear gradient polyacrylamide gel electrophoresis. Analyt. Biochem. 87, 386-396.

Nicander, L. \& Ploen, L. (1979) Studies on regional fine structure and function in the rabbit epididymis. Int. J. Androl. 2, 463-481.

Olson, G.E. \& Gould, K.G. (1981) Characterization of sperm surface and seminal plasma glycoproteins of the chimpanzee. J. Reprod. Fert. 62, 185-191.

Olson, G.E. \& Hamilton, D.W. (1978) Characterization of the surface glycoproteins of rat spermatozoa. Biol. Reprod. 19, 26-35.

Orgebin-Crist, M.C. \& Jahad, N. (1978) The maturation of rabbit epididymal spermatozoa in organ culture: inhibition by antiandrogens and inhibitors of ribonucleic acid and protein synthesis. Endocrinology 103, 46-53.

Orgebin-Crist, M.C. \& Jahad, N. (1979) The maturation of rabbit epididymal spermatozoa in organ culture: stimulation by epididymal cytoplasmic extracts. Biol. Reprod. 21, 511-515.

Reid, B.L. \& Cleland, K.W. (1957) The structure and function of the epididymis. I. The histology of the rat epididymis. Aust. J. Zool. 5, 223-246.

Reynolds, E.S. (1963) The use of lead citrate at high $\mathrm{pH}$ as an electron-opaque stain in electron microscopy. $J$. Cell Biol. 17, 208-212. 
Sedar, A.W. (1966) Transport of exogenous peroxidase across the epithelium of the ductuli efferentes. $J$. Cell Biol. 31, 102A, Abstr.

Temple-Smith, P.D. \& Bedford, J.M. (1976) The features of sperm maturation in the epididymis of a marsupial, the brushtailed possum Trichosurus vulpecula. Am. J. Anat. 147, 471-500.

Temple-Smith, P.D. \& Bedford, J.M. (1980) Sperm maturation and the formation of sperm pairs in the epididymis of the opossum, Didelphis virginiana. $J$. exp. Zool. 214, 161-171.

Turner, T.T., Hartmann, P.K. \& Howards, S.S. (1977) Invivo sodium, potassium, and sperm concentrations in the rat epididymis. Fert. Steril. 28, 191-194.

Ullich, K.J., Fromter, E. \& Baumann, K. (1969) Micropuncture and microanalysis in kidney physiology. In Laboratory Techniques in Membrane Biophysics, pp. 106-129. Eds H. Passon \& R. Stämpfli. SpringerVerlag, Berlin.
Umbreit, W.W., Burris, R.H. \& Stauffer, O.F. (1972) Manometric and Biochemical Techniques, 5th edn, p. 146. Burgess Publishing Company, Minneapolis.

Watson, M.L. (1958) Staining of tissue sections for electron microscopy with heavy metals. J. Biophys. Biochem. Cytol. 4, 475-478.

White, I.G. \& Wales, R.G. (1961) Comparison of epididymal and ejaculated semen of the ram. $J$. Reprod. Fert. 2, 225-237.

Wyker, R. \& Howards, S.S. (1977) Micropuncture studies of the motility of rete testis and epididymal spermatozoa. Fert. Steril. 28, 108-112.

Young, W.C. (1931) A study of the function of the epididymis. II. Functional changes undergone by spermatozoa during their passage through the epididymis and vas deferens in the guinea pig. $J$. exp. Biol. 8, 151-163.

Received 16 December 1982 